Vol. 23, No. 1, Maret 2020, hlm. 35-44

p-ISSN: 1410-9344; e-ISSN: 2549-5631

homepage: http://journals.ums.ac.id/index.php/warta

\title{
Pemberdayaan Jurnalistik bagi Organisasi Kepemudaan Masjid pada FORSAM Klaten Selatan
}

\author{
Vinisa Nurul Aisyah \\ Program Studi Ilmu Komunikasi, Fakultas Komunikasi dan Informatika UMS \\ Email:vna409@ums.ac.id
}

\section{Article Info \\ Submitted: 8 Oktober 2019 \\ Revised: 17 Oktober 2019 \\ Accepted: 26 November 2019 \\ Published: 2 Januari 2020}

Keywords: Forsam Klaten Selatan, journalistic, writing techniques
Kata kunci: Forsam Klaten Selatan, jurnalistik, teknik penulisan

\begin{abstract}
News and information not only belong to journalist or mass media. Since the development of the internet, information belong to everyone. Society as an active audience should improve their literacy digital, not only consuming the news but also producing the news through internet especially website. One of the youth organizations Forum Silaturahmi Antarmasjid (Forsam) Klaten Selatan, responded the information needs of the digital era by creating an official forum, the website forsamklaten. com. The website has an important role in the organization. First, the internal side, namely as a forum for members to improve their writing ability. Second, on the external side, the website becomes the official media that conveys information, Forsam's schedule of activities and agendas and their networks. The presence of this website then needs to be balanced by increasing the ability to write members' websites so that this website writing training is carried out. The training method is carried out in three ways namely explanation, writing practices then evaluation and writing assistance. The explanation session emphasized the initial explanation of journalistic principles in general while the practice of writing and evaluation focused more on the active participation of workshop participants. This activity is also some recommendations for the sustainability of website management, namely the creation of structures for website administrators, more specific rubrics, making picket schedules and adding website features related to the FORSAM Klaten Selatan network link. Through this training, it is expected that there will be an increase in the competence of members of Forsam Klaten Selatan in the field of writing so that they are able to manage their website optimally.
\end{abstract}

Abstrak
Informasi bukan milik media massa dan wartawan saja. Sejak
berkembangnya internet, informasi bukan menjadi hal yang sulit
didapatkan. Peran masyarakatsebagaikhalayakaktifdalampenyebaran
informasi melalui dunia maya ini perlu diimbangi dengan kemampuan


penulisan website. Salah satu organisasi kepemudaaan, Forum Silaturahmi Antarmasjid (FORSAM) Klaten Selatan merespon baik kebutuhan informasi dalam era digital dengan membuat wadah resmi yaitu website FORSAMklaten.com. Website memiliki peran penting dalam organisasi melalui. Pertama, sisi internal, yaitu sebagai wadah anggota untuk menyalurkan potensi di budang tulis menulis. Kedua, sisi eksternal, website menjadi media resmi yang menyampaikan informasi, jadwal kegiatan dan agenda FORSAM beserta jaringannya. Kehadiran website ini kemudian perlu diimbangi dengan peningkatan kemampuan penulisan website anggota sehingga dilaksanakan pelatihan penulisan website ini. Metode pelatihan dilakukan dengan tiga cara yaitu ceramah, praktik penulisan kemudian evaluasi dan pendampingan penulisan. Sesi ceramah menekankan penjelasan awal tentang prinsip-prinsip jurnalistik secara umum sementara praktik penulisan dan evaluasi lebih menekankan pada partisipasi peserta workshop. Kegiatan ini juga beberapa rekomendasi untuk keerlanjutan pengelolaan website yaitu pembuatan struktur untuk pengurus website, rubrikasi yang lebih spesifik, pembuatan jadwal piket dan penambahan fitur website terkait dengan link jaringan FORSAM Klaten Selatan. Melalui pelatihan ini diharapkan adanya peningkatan kompetensi anggota FORSAM Klaten Selatan di bidang tulis menulis sehingga mampu mengelola website mereka secara optimal.

\section{PENDAHULUAN}

Kemampuan menulis, baik jurnalistik mau pun non jurnalistik merupakan salah satu kemampuan literasi yang harus dimiliki generasi milenal. Singgungan dengan internet yang tak bisa dihindarkan menjadi salah satu faktornya. Perkembangan distribusi informasi yang serba cepat dan mudah kemudian menggerakan masyarakat sebagai khalayak aktif yang tak hanya menerima informasi tapi juga sebagai pembuat pesan melalui website.

Generasi milenial merupakan generasi pengguna internet aktif. Kemampuan literasi digital perlu dimaksimalkan agar dapatmencegah dampak negatif adanya kemelimpahan informasi yang ada di internet. Posisi generasi milenal ditegaskan melalui Asosiasi Penyelenggara Jasa Internet Indonesia (APJII). Dalam laporan survey tahunannya, dinyatakan angka pengguna internet Indonesia 2016 yang mencapai 132,7 juta dimana pengguna paling banyak berasal dari umur 35 hingga 44 tahun dan umur 25-34 tahun sebanyak 24,4\%. (APJII,2016:7).

Kehadiran internet sebagai teknologi komunikasi tidak serta menghilangkan peran media tradisional seperti koran dan majalah.
Dalam penelitiannya, Salman et al. (2011:3) menjelaskan bahwa media-media tradisonal sebaiknya mulai mengadopsi internet sebagai sumber distribusi informasi mereka. Banyaknya media yang beralih ke teknologi digital patut diikuti oleh kelompok masyarakat lain. Sehingga informasi dapat dengan cepat diterima oleh audiens.Pengguna internet yang mampu memproduksi berita sering disebut dengan citizen journalist. 'Citizen journalism', to use the phrase suddenly appearing in mainstream news items, was being supplemented by other forms of reporting similarly made possible by digital media (Allan, 2006:45).

Di Indonesia, kehadiran citizen journalism merupakan hal yang sejalan dengan demokratisasi. Nafas demokrasi sebagai bentuk negara Indonesia mewarnai di setiap dinamika kehidupan. Demokrasi dan kebebasan berpendapat ibarat dua sisi mata uang. Keduanya merupakan dua hal yang tak bisa dipisahkan. Secara luas, dunia memberikan pengakuan atas kebebasan untuk mencari, mengumpulkan, dan untuk menyebarluaskan informasi sebagaimana yang disuarakan dalam piagam PBB. Piagam PBB itu kemudian diimplementasi melalui UUD 
1945. Pasal 19 UUD 1945 berbunyi: "Setiap orang berhak atas kebebasan berpendapat atau mengeluarkan pendapat; hal itu meliputi kebebasan mempertahankan pendapat dengan tanpa gangguan, serta mencari, menerima, dan meneruskan segala informasi dan gagasan, melalui media apapun dan tanpa memandang batas."

Seiring perkembangan teknologi khususnya internet, media penyampai pendapat juga semakin banyak. Mulai dari jejaring sosial, surat elektronik dan lainnya kini tersedia. Bentuk kebebasan berpendapat yang didukung perkembangan teknologi ini yang disebut dalam paper research yang dibuat Hartley (2008:2) mendukung jurnalisme sebagai hak asasi manusia. Hartley memandang jurnalisme seharusnya mampu menjawab persoalan terbungkamnya aspirasi manusia. Apalagi, didukung oleh perkembangan teknologi pasca penemuan mesin cetak, internet, yang mampu membuat semua orang menyampaikan dan mendistribusikan gagasan dengan mudah.

Hartley (2008:3) mengatakan dalam kamus Oxford Advanced Learner's Dictionary of Current English definisi jurnalisme adalah: (a). The work of profession of producing; (b) Writing that may be all right for a newspaper. Citizen Journalism memang merupakan kerja amatir yang menawarkan alternatif tersendiri tentang sebuah kerjajurnalistik, yakni menginformasikan kejadian, fakta, realitas kepada masyarakat yang dapat diakukan oleh siapapun. Sebab citizen journalism bisa dikerjakan siapapun bahkan yang tak memiliki latar belakang jurnalistik.

Berdasarkan penelitian Kurniawan (2007:71) citizen journalism ini berawal dari stasiun radio Elshinta sejak tahun 2000, dan hingga kini Elshinta punya 100.000 reporter warga. Namun, media mainstream lain seperti stasiun TV, media cetak, website di Indonesia terlihat masih enggan untuk mengadopsi jurnalisme warga dalam praktik jurnalisme mereka karena takut kehilangan kredibilitas, reputasi dan problem etika jurnalistik. Penelitian Kurniawan tersebut membahas tentang bagaimana Elshinta mengantisipasi masalah etik dan hukum atas berita reporter warga dengan menerapkan prosedur operasi standar. Perangkat lunak dipakai untuk mencatat identitas reporter warga dan beritanya. Nunung menyatakan citizen journalism di Indonesia sudah ada pada jalur yang benar.

Kehadiran citizen journalism kental dengan semangat kebebasan berpendapat manusia dan kritik media mainstream yang bernafaskan kapitalisme. Di Indonesia sendiri ada banyak media yang merupakan perpanjangan tangan kelompok politik. Sebab beberapa media dimiliki oleh politikus. Hal ini dijelaskan Daulay dan Zacky (2010:4) bahwa citizen journalism merupakan alat kontrol yang sangat produktif bagi terciptanya ruang publik, dan tempat partisipasi politik warga negara. Dalam perspektik Habermas, fenomena ini disebut demokrasi deliberatif atau dialogis yang dapat mencairkan konflik-konflik yang terjadi, sehingga konflik yang terjadi dapat diredam melalui musyawarah (deliberatif).

Di Indonesia, citizen journalism pun mulai muncul. Sebuah studi di Indonesia mencatat bahwa pada tahun 2009 terdapat peningkatan jumlah aktivitas citizen jurnalisme (Wijayana \& Luqman, 2009). Karya jurnalistik yang dibuat oleh warga Indonesia adalah rekaman tsunami Aceh pada tahun 2004 lalu. Saat itu, musibah tersebut direkam dan diunggah oleh warga. Media umum sendiri saat itu sulit menjangkau wilayah yang terkena tsunami, sehingga karya citizen journalism itu menjadi rujukan utama dalam pemberitaan. Rappaport (2007:64) menegaskan bahwa citizen journalism memberikan kesempatan besar pada siapapun untuk dapat terlibat dalam proses pengumpulan berita dan penyiaran berita. Masyarakat yang sebelumnya hanya menjadi konsumen berita (pada media koran dan televisi) kini dapat menjadi aktor dalam jurnalistik.

Antara produsen dan konsumen berita tidak bisa lagi diidentifikasi secara rigid karena setiap orang memerankan keduanya (Gillmor,2004: xii). Hal ini menimbulkan tantangan baru bagi model jurnalisme ini. Jika dalam media konvensional atau umum, berita dibuat oleh kalangan profesional, berita dalam citizen journalism dibuat kalangan non profesional. Sementara kalangan professional mendapatkan pendidikan jurnalistik, warga tidak. Hal ini tentu menjadi pemicu perbedaan kualitas produknya. 
Forum Silaturahmi Antar Masjid (FORSAM) sebagai organisasi kepemudaan memahami perkembangan situasi tersebut. Oleh karena itu FORSAM menyadari perlunya pelatihan teknik penulisan website sebagai salah satu kebutuhan dasar mereka sebelum berkecimpung di dunia maya melalui website resmi. FORSAM Klaten merupakan organisasi kepemudaan yang memiliki anggota dari rentang usia yang besar, mulai dari usia 15 hingga 25 tahun yang dibentuk atas inisiasi pemuda masjid yang juga merupakan warga Muhammadiyah sebagai wadah untuk komunikasi pemuda antar masjid di wilayah Klaten. Sebelum website diinisiasi, FORSAM mengandalkan Group dalam aplikasi WhatsApp untuk berkomunikasi. Karena sifat group yang tertutup dan terbatas dalam fiturnya, maka FORSAM membutuhkan ruang yang lebih luas dan terbuka.

Selain aplikasi WhatsApp, FORSAM juga membuat akun dalam media sosial Instagram dengan username @FORSAM_forumremaja. Namun akun ini juga dirasa kurang efektif karena terbatas hanya pada gambar saja. Akun yang memiliki 75 follower ini kemudian mulai ditinggalkan. Dari sisi internal, penggunaan website mampu menjadi wadah pemberdayaan bagi anggotanya. Selain itu dengan menggunakan website, informasi kegiatan dan agenda internal juga dapat terpantau melalui website. Misalnya jadwal pengajian rutin dan lokasi dalam satu bulan yang bisa di bagikan dengan mudah dalam website. Hal ini merupakan hasil dari analisis organisasi internal FORSAM yang mempunyai potensi dalam dunia tulis menulis namun belum memiliki ruang untuk menjembatani kekuatan tersebut.

Kondisi ini dimanfaatkan dengan baik FORSAM Klaten Selatan melalui inisiasi pembuatan dan pengelolaan website untuk sumber informasi sekaligus ruang pemberdayaan internal. Secara garis besar, Menurut Zaki (2009), website memiliki fungsi sebagai media promosi, pemasaran, informasi, pendidikan dan komunikasi. Fungsi tersebut disesuaikan dengan kebutuhan FORSAM Klaten Selatan yaitu media informasi, pendidikan dan komunikasi. Awal pembuatan website ini mempunyai dua tujuan utama, pertama tujuan internal yaitu sebagai media untuk menyebarkan agenda antar masjid sekaligus ruang untuk mengembangkan potensi di bidang kepenulisan anggotanya. Kedua yaitu kepentingan eksternal yaitu untuk sarana dakwah bagi masyarakat secara luas.

Pemanfaatan website ini merupakan kegiatan positif. Internet dapat digunakan sebagai ruang diskusi dan berpendapat. Hal tersebut sesuai dengan apa yang disampaikan Nurudin (2010:66) sebagai kelebihan citizen journalism yaitu mendorongnya iklim demokratisasi, memupuk budaya tulis dan baca masyarakat, menciptakan ruang publik dan kontrol sosial. Selain itu, dalam penelitian milik Allan (2007:19) dijelaskan bahwa gagasan publik yang mulai berbagi informasi melalui medianya sendiri merupakan perkembangan positif. Proses berbagi informasi melalui teknologi digital dapat membawa informasi, perspektif dan ideologi alternatif di tengah-tengah krisis nasional.

Website FORSAM Klaten Selatan dengan alamat FORSAMklaten.com ini sebenarnya bukan produk digital pertama. Sebelumnya FORSAM Klaten Selatan sudah menggunakan media sosial Instagram dan Facebook. Namun media sosial dirasa belum cukup mewadahi sebab ia terbatas dalam hal kapasitas tulisan dan fitur yang cenderung merujuk pada komunikasi interpersonal. Website dipilih sebagai media yang sesuai dengan generasi remaja serta memiliki fitur yang lebih luas daripada media sosial. Menurut Harminigtyas (2014:39), website anda adalah sebuah tempat di internet, siapa saja di dunia ini dapat mengunjunginya, kapan saja mereka dapat mengetahui informasi di dalamnya. Sehingga tidak berlebihan jika pemilihan website merupakan pilihan tepat bagi FORSAM Klaten Selatan sebagai cara untuk menampilkan diri sekaligus organisasi FORSAM Klaten Selatan di internet.

Teknik penulisan website berbeda dengan penulisan pada media cetak. New media system embraces all forms of human communication in a digital format where the rules and constraints of the analog world no longer apply" (Pavlik, 2001:xii), sehingga perlu adanya pemahaman terkait dengan penulisan di dunia digital khususnya website. Mendorong partisipasi aktif kaum pelajar dalam membangun kesadaran dunia tulis menulis, tentu saja harus diimbangi dengan peran aktif pula oleh semua pihak (Makhrus \& Cahyani, 2016:42) Dalam rangka 
pendirian dan pengelolaan, FORSAM terbentur beberapa permasalahan diantaranya adalah kemampuan pengurus dalam hal kepenulisan hingga teknis pengisian konten website.

Dengan permasalahan demikian, maka solusi yang dilakukan adalah dengan pemberian pelatihan teknik penulisan website baik berupa tulisan berita dan non berita. Penulisan berita dilakukan untuk menuliskan kegiatan internal FORSAM sementara non berita untuk tulisan dakwah atau opini anggota terkait dengan fenomena yang sedang booming di masyarakat. Kegiatan pelatihan teknik penulisan website bertujuan untuk mengenalkan pada anggota jenis-jenis tulisan yang ada dalam website. Setelah pelaksaan pelatihan ini diharapkan anggota FORSAM mampu memproduksi tulisan secara konsisten dan beragam jenisnya.

\section{METODE}

Kegiatan pengabdian ini dilaksanakan di Ruang Kajian Yayasan Al-Bayan, Klaten Selatan pada tanggal 25 Februari 2018. Pelatihan ini merupakan kerjasama antara FORSAM dengan pelaksana yang berkolaborasi dengan dosen FKIP UMS.Pelaksana memiliki pertimbangan terkait dengan pemilihan organisasi FORSAM Klaten Selatan. FORSAM Klaten Selatan merupakan organisasi yang aktif dan mandiri dibanding dengan organisasi kepemudaan lainnya. Keaktifan dinilai dari banyak dan rutinitas kegiatan FORSAM Klaten Selatan. Selain itu FORSAM Klaten Selatan merupakan organisasi yang besar, sebab ia membawahi forum remaja masjid se-Klaten sehingga tidak mengherankan ia membutuhkan website sebagai wadah informasi sekaligus pemberdayaan anggotanya. Pelatihan ini menggunakan tiga metode, pertama penyampaian teori dan teknik penulisan website, kedua praktik penulisan dan ketiga forum diskusi dan evaluasi hasil tulisan.

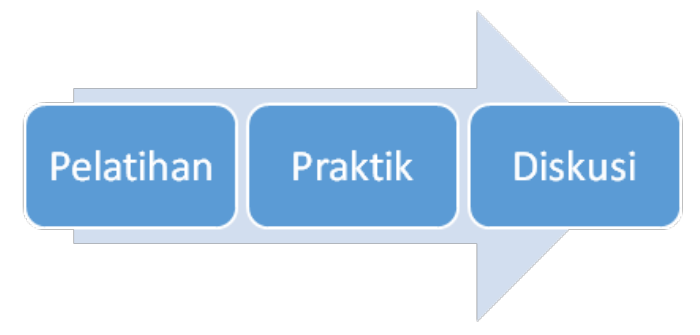

Gambar 1. Proses pengabdian
Pertama yaitu penyampaian materi berupa karakteristik website sebagai media, jenis tulisan pada website, struktur tulisan pada website, contoh tulisan dan bagaimana mencari ide sebelum menulis. Pada sesi ini peserta pelatihan juga melakukan sesi tanya jawab disela-sela penyampaian. Tahap kedua setelah pelatihan adalah praktik penulisan. Pada sesi ini pelaksana lebih menekankan pada pendampingan praktik. Pelaksana mendampingi peserta mulai dari pencarian ide tulisan, menyusun kerangka tulisan dan eksekusi penulisan. Ketiga yaitu sesi forum diskusi hasil tulisan. Pada sesi ini pelaksana membahas satu per satu hasil tulisan peserta. Selain itu peserta lain diminta untuk berkomentar tentang hasil tulisan teman mereka. Hal ini ditujukan agar mereka mengerti mana tulisan yang efektif dan tidak. Sehingga peserta pelatihan bisa belajar dari kesalahan yang dilakukan diri sendiri sekaligus orang lain.

\section{HASIL DAN PEMBAHASAN}

Salah satu kemampuan yang harus diingkatkan dalam era digital ini yaitu produksi dan reproduksi pesan yang seiring dengan perkembangan teknologi kemudian difasilitasi oleh internet. Tak dapat dipungkiri, kemampuan produksi pesan melalui jenis pesan jurnalistik dan non jurnalistik menjadi kemampuan yang tidak didapatkan di bangku sekolah. Hal ini tentu menjadi nilai lebih dalam pelaksanaan pelatihan ini. FORSAM Klaten Selatan sebagai salah satu organisasi di masyarakat merupakan salah satu kelompok pemberdayaan di masyarakat. Dalam kegiatannya, pengurus harus menetapkan berbagai program guna meningkatkan daya anggotanya.

Setelah pelatihan penulisan website ini selesai, pelaksana melakukan pendampingan anggota FORSAM Klaten Selatan untuk pengembangan dakwah digital. Hal tersebut dilakukan dengan melakukan sharing tulisan melalui aplikasi whatsapp atau email. Selain itu karena bentuk media yag digital, pelaksana juga mampu memantau perkembangan website. Sebelum dilakukan pelatihan penulisan, FORSAM Klaten Selatan belum memiliki rubrikasi yang jelas. Beberapa tulisan masih acak dalam kategori umum. Hal ini terjadi karena anggota masih minim dalam hal jenis-jenis tulisan. 
Setelah dilaksanakan pelatihan, anggota mampu membuat kategori berdasarkan jenis tulisan secara garis besar. Misalnya mana yang termasuk berita, nonberita dan info grafis.

Kegiatan pelatihan penulisan website berhasil dilakukan pada Dalam pelaksanannya, pelatihan ini berlokasi di Ruang Kajian Yayasan Al-Bayan RT 3 RW 8 nomor 22 Kaloran Kelurahan Gayamprit Kecamatan Klaten Selatan pada hari Minggu, 25 Februari 2018 yang diikuti oleh 17 orang. Materi pertama yang disampaikan pelaksana yaitu mengenai bagaimana teknik penulisan di website. Pemateri membedakan website dan media cetak sebagai perbandingan. Bahasan berikutnya tentang jurnalisme. Jurnalisme menurut Nurudin (2009:9) adalah kegiatan yang berhubungan dengan proses mencari, mengolah dan menyiarkan informasi melalui media massa.

Dalam penulisan jurnalisme, materi dibagi menjadi dua yaitu teknik penulisan berita dan non berita pada website. Pemahaman terkait jenis tulisan yang dapat diwadahi website menjadi penting. Hal ini disebabkan pada keterbatasan pengetahuan peserta terkait dengan jenis tulisan. Pada tahap awal, pelaksana menjelaskan definisi berita, peristiwa yang mempunyai nilai berita dan tidak mempunyai nilai berita terlebih dahulu sebelum fokus pada penulisan di website.

Setelah memahami prinsip dasar berita, materi selanjutnya yaitu teknik penulisan berita. Pemateri menjelaskan dalam teknik penulisan berita ada tiga jenis pemberitaan, yaitu hard news atau straight news, indepth news dan feature. Hard news merupakan berita cepat yang sering di temui di website sebab cocok dengan potensi website yang memungkinkan kecepatan dalam penyebaran informasi. Hard news sendiri terdiri dari $5 \mathrm{~W}$ yaitu who, when, where, why, serta what dan $1 \mathrm{H}$ yaitu how yang disusun seperti piramida terbalik. Semakin ke bawah maka semakin tidak penting informasinya.

Kedua yaitu indepth news merupakan perpanjangan dari hard news, ia tidak hanya menjelaskan unsur $5 \mathrm{~W}$ dan $1 \mathrm{H}$ dalam sebuah peristiwa tapi bagaimana analisis terkait fenomena tersebut. Pembaca disuguhi perspektif berbeda dengan analisis tersebut. Jenis terakhir yaitu feature, merupakan jenis tulisan yang menitikberatkan pada human interest. Feature merupakan kebalikan dari hard news sebab ia tidak mementingkan kecepatan penyebaran informasi. Struktur tulisannya pun lebih lentur, tergantung dari keinginan si penulis. Pelaksana menyarankan anggota FORSAM Klaten Selatan untuk fokus pada dua jenis tulisan berita terdahulu, straight news dan feature.

Setelah menjelaskan teorinya, pemateri kemudian menyuguhkan lampiran hand out berupa contoh jenis tulisan dari media konvensional yang diambil melalui website. Pemateri mengajak berdiskusi bahwa kondisi media online atau website sekarang harus pintar menarik pembaca. Jangan hanya mengandalkan tulisna tapi juga foto, indeks, infografik dan analisis visual yang mampu menyederhanakan data. Hal ini penting agar pembaca tidak bosan melihat website yang hanya ebrisi tulisan saja.

Tak hanya materi terkait praktik, dalam diskusi juga membekali peserta dengan prinsipprinsip dasar jurnalisme yang dapat diterapkan di website organisasi. Menurut Harsono (2016), prinsip jurnalisme merupakan hal penting yang membedakan produk jurnalistik dan non jurnalistik. Prinsip-prinsip tersebut berhubungan dengan etika jurnalistik. Pertama, objektif. Objektifitas dalam produk jurnalistik yaitu bagaimana disiplin dalam melakukan verifikasi. Dalam hal website FORSAM Klaten Selatan, prinsip objektif dapat diterapkan dengan cara menyebutkan sumber lebih dari satu dan adanya pemeriksaan ulang sebelum konten di upload. Penerapan prinsip ini memerlukan adanya admin khusus website untuk mengecek tulisan yang akan ditayangkan.

Prinsip kedua yaitu menarik. Konten yang menarik akan membuat audiens atau pembaca lebih mudah untuk memahami isi pesan. Bukan berarti isi berita merupakan gosip namun gaya bahasa yang meneyesuaikan dengan pembaca (Harsono, 2016). Dalam penerapannya, prinsip menarik ini dapat disesuaikan dengan pembaca website FORSAM Klaten Selatan yang merupakan remaja. Pemateri menawarkan penggunaan bahasa yang mudah dipahami dan tidak kaku.

Setelah itu materi selanjutnya dalah teknik penulisan non berita pada website. Pada materi ini terdiri dari dua sub bab, pertama opini dan kedua esai. Opini merupakan pendapat kita atas 
fenomena atau kejadian di sekitar kita. Kedua hampir sama untuk struktur penulisannnya, terdapat tiga bagian yaitu pembuka isi - penutup. Pada Esai, penulis harus menambahkan analisis ilmiah yang diambil dari berbagai literature sebagai pembanding atau alat analisis untuk menguatkan pendapat kita. Sementara opini lebih santai dan bebas dalam penulisannya.

Penulisan opini perlu dimulai dengan kepekaan anggota pada masalah-masalah yang ada di sekitar mereka. Hal ini bertujuan agar sumber-sumber ide tulisan opini dapat ditemukan dengan mudah. Cara lain dalam menemukan ide untuk penulisan opini yaitu dengan melihat hari-hari besar yang ada pada kalender. Sebagai contoh, tanggal 2 Mei yang diperingati sebagai Hari Pendidikan Nasional. Opini dapat dijadikan sebagai ruang reflektif bagaimana penulis menyikapi isu pendidikan yang saat ini berkembang di Indonesia.

Setelah selesai menjelaskan dan tanya jawab pada sesi teori, sesi selanjutnya yaitu praktik. Pemateri meminta peserta untuk memilih salah satu dari dua jenis tulisan dalam website, berita atau non berita. Hampir 90 persen peserta menuliskan opini sementara sebagian kecil memilih menulis berita. Selama hampir dua jam mereka menuliskan kemudian dilanjutkan dengan diskusi satu per satu hasil tulisan mereka untuk mendapatkan kritik sehingga mereka mampu memperbaiki tulisan mereka di kemudian hari.

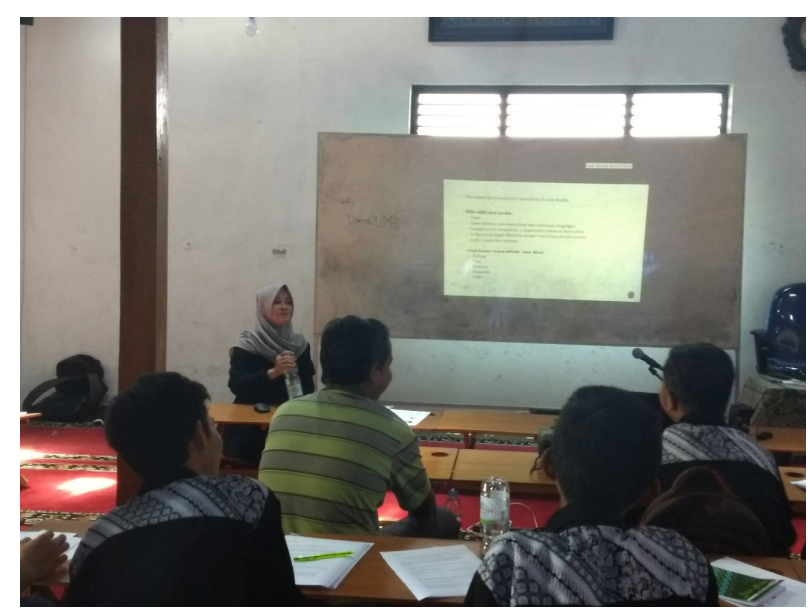

Gambar 2. Sesi Tanya Jawab pada Pelatihan Penulisan Website
Sesi selanjutnya yaitu diskusi penutup terkait keberlanjutan dalam penulisan website. Dalam diskusi tersebut terdapat beberapa rencana strategis yang dapat dijadikan rujukan FORSAM Klaten Selatan. Ada beberapa tahapan pengembangan yang dilakukan oleh pelaksana dengan mitra.

Pertama, membuat struktur dalam website. Meski FORSAM Klaten sudah memiliki struktur sendiri, namun website belum termasuk di dalamnya. Hal ini dapat menyebabkan macetnya postingan atau tidak teraturnya update agenda dalam website. Struktur dapat menyelesaikan permasalahan ritme postingan yang belum teratur. Dengan membuat struktur maka penanggungjawab website jelas dan garis koordinasinya pun bisa dibuat tegas. Sehingga jika terjadi masalah, pengurus yang berwenang mampu mengambil keputusan. Dalam hal kemungkinan pelaksanaan, pembuatan struktur ini sangat mungkin untuk dilaksanakan dengan persetujuan ketua.

Kedua, membuat rubrikasi dalam website. Rubrikasi dalam website merupakan hal yang penting dan dapat dilakukan oleh FORSAM. Rubrikasi merupakan proses kategorisasi berdasarkan konten tulisan. Misalnya ada rubrikasi: agenda masjid yang berisi jadwal pengajian di masjid wilayah Klaten, seputar klaten yang berisi tentang berita-berita umum di sekitar Klaten, Kajian Islam yeng berisikan tentang nilai, ajaran dan lain-lain yang berkaitan dengan Islam dan Muhammadiyah. Selain itu rubric lain-lain dapat digunakan untuk menampung karya yang tidak berhubungan dengan berita atau kegiatan FORSAM. Misalnya karikatur, fotogafi atau kuliner di Klaten.

Ketiga membuat jadwal piket pengurus. Jadwal piket merupakan salah satu rencana yang mungkin untuk dilakukan. Melalui penjadwalan per minggu, yang bertanggung jawab bukan hanya coordinator website saja namun seluruh pengurus. Melalui jadwal, pengurus juga akan dimudahkan menyusun rencana penulisan atau liputan. Jadwal piket untuk FORSAM bisa disesuaikan jumlah pengurus dan kesibukan agenda masing-masing. Bisa dibuat per minggu, per dua minggu atau per bulan.

Keempat, menambahkan fitur baru terkait dengan jaringan FORSAM Klaten Selatan sebagai 
sebuah organisasi. Dalam rangka menyelesaikan permasalahan website yang belum dikenal, FORSAM dapat mencantumkan jaringan di website resminya. Rencana ini merupakan rencana yang mungkin dilakukan sebab sangat mudah. Hanya saja pelaksanaan membutuhkan izin dari jaringan yang nantinya akan digunakan. Dalam dunia maya, website merupakan hal yang bisa dimiliki siapa saja. Oleh karena itu FORSAM membutuhkan kredibilitas untuk membuktikan bahwa websitenya merupakan website resmi. Salah satunya dengan mencantumkan jaringan misalnya, website Muhammadiyah pusat atau daerah Klaten. Selain itu dengan mencantumkan organisasi lain seperti KOKAM, IMM dan lainnya akan menguntungkan bagi FORSAM yang barus aja merintis website resminya.

Kegiatan terakhir yaitu pelaksana memberikan hadiah pada beberapa peserta yang dinilai mempunyai antusias dan usaha maksimal dalam pelatihan ini. Hadiah tersebut yaitu alat yang dapat mendukung kegiatan pemberdayaan jurnalistik di FORSAM Klaten Selatan yaitu paket data dan modem internet. Harapannya, alat tersebut dapat memudahkan peserta di

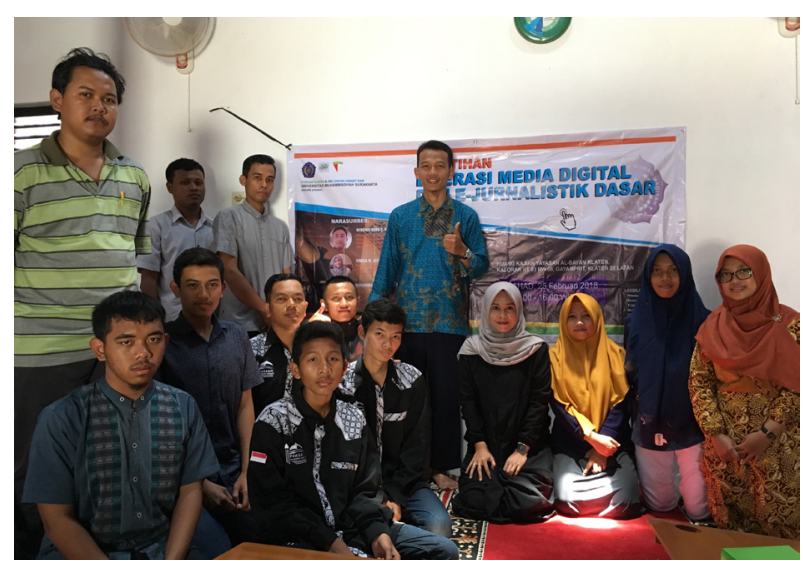

Gambar 3. Pelaksana dan Mitra Melakukan Foto Bersama Usai Pelatihan

kemudian hari. Kemudian penutupan dilakukan oleh pemateri ketiga dan bacaan hamdalah.

Selain materi yang disampaikan melalui lisan oleh pelaksana, peserta pelatihan juga mendapatkan handout. Melalui handout tersebut diharapkan menjadi pedoman di kemudian hari. Hand out tersebut merupakan bahan yang sudah disiapkan oleh pelaksana. Berikut ini isi materi yang disajikan :

Tabel 1. Tabel Materi Pelatihan

\begin{tabular}{ll}
\hline \multicolumn{1}{c}{ Materi } & \multicolumn{1}{c}{ Uraian } \\
\hline Website sebagai Media Massa & Jenis-jenis website, Fitur dalam website, kelemahan dan kelebihan \\
& website, contoh website portal berita dan komunitas \\
Jenis tulisan & Karakteristik tulisan berita \\
& Jenis berita : straight news dan feature \\
& Teknik penulisan berita straight news dan feature \\
& Prinsip-prinsip dalam jurnalisme \\
& Karakteristik tulisan non berita \\
& Jenis tulisan : opini, esai, sastra \\
& Teknik penulisan opini dan esai \\
& Struktur \\
& $5 \mathrm{~W}+1 \mathrm{H}$ \\
Straight news & Contoh penulisan \\
& Struktur \\
Feature & Lead, body, ending \\
& Contoh penulisan \\
& Lead, body, ending \\
Opini & Bagaimana menulis opini ; \\
& Struktur esai \\
Esai & Contoh tulisan esai \\
Penulisan Sastra, info grafik & Info grafik, penulisan sastra yang efektif \\
\hline &
\end{tabular}




\section{SIMPULAN}

Setelah dilaksanakan pelatihan penulisan website untuk anggota FORSAM Klaten Selatan dalam mengoptimalkan penggunaan website, kesimpulan yang dapat disampaikan adalah bahwa organisasi kepemudaan sebaiknya peka dan mulai memanfaatkan ruang-ruang digital untuk kepentingan pemberdayaan anggota dan pusat informasi. Selain itu, kegiatan pelatihan penulisan website memberikan kontribusi positif dalam mengenalkan jenis tulisan. Sebelumnya mereka mengandalkan dari situs jaringan FORSAM Klaten Selatan seperti Muhammadiyah kini mereka dapat membuat produk tulisan secara mandiri. Namun demikian, website FORSAM Klaten Selatan merupakan media yang membutuhkan keberlangsungan berita dan konsistensi anggotanya untuk terus menghidupi ruang ini. Dengan demikian, kegiatan pelatihan perlu dilakukan secara berkala. Selain itu, dalam rangka pengabdian selanjutnya perlu direncanakan pengembangan dakwah bentuk karikatur, desain grafis, maupun info grafis agar website lebih menarik.

\section{PERSANTUNAN}

Penulis mengucapkan banyak terima kasih kepada Universitas Muhammadiyah Surakarta atas dukungannya dalam membantu kelangsungan acara serta peserta dari FORSAM Klaten Selatan yang sudah hadir dalam acara pelatihan ini. Selain itu penulis juga mengucapkan terima kasih pada pihak-pihak lain yang terlibat dan mendukung pelaksanaan pengabdian kepada masyarakat ini.

\section{REFERENSI}

Allan, Stuart. (2006). Online News Journalism and The Internet. New York ; Open University Press.

Allan, Stuart. (2007). Citizen Journalism and The Rise of 'Mass Self-Communication": Reporting the London Bombings. Global Media Journal Sutralian Edition Issue 1, Volume 1:2007.

APJII (Asosiasi Penyelenggara Jasa Internet Indonesia). (2016). Penetrasi dan Perilaku Pengguna Internet Indonesia Survey 2016.

Daulay, Pardamean dan Muhamamd Jacky. (2010). Menelusuri Perkembangan Journalisme Warga dan Dampaknya Terhadap Demokratisasi di Indonesia. Skripsi UT.

Gillmor, Dan. (2004). We The Media: Grassroot Journalism By The People For The People. United States: O’Reilly Media Inc

Harminingtyas, Rudika. (2014). Analisis Layanan Website Sebagai Media Promosi, Media Transaksi dan Media Informasi dan Pengaruhnya terhadap Brand Image Perusahaan Hotel Ciputra di Kota Semarang. Jurnal STIE SEMARANG, VOL 6, No. 3, Edisi Oktober 2014.

Hartley, John. (2008). Journalism as A Human Right: The Cultural Approach to Journalism. In Loffelholz, Martin \& Weaver, David (Eds.) Global Journalism Research: Theories, Methods, Findings, Future. Blackwell Publishing, New York, pp. 39-51.

Harsono, Andreas. (2016). A9ama Saya Adalah Jurnalisme. Yogyakarta : PT Kanisius.

Kurniawan, M.N.. (2007). Jurnalisme Warga Di Indonesia, Prospek Dan Tantangannya. Makara Seri SosialHumaniora, 11(2), 71-78. DOI:10.7454/mssh.v11i2.115

Makhrus dan Putri Dwi Cahyani. (2016). Pelatihan Creative Writink pada Ikatan Pelajar Muhammadiyah Kabupaten Banyumas. Jurnal Islamadina, Volume XVII, No 2 Juni 2016.

Nurudin. (2009). Pengantar Komunikasi Massa. Jakarta: Rajawali Pers.

Nurudin. (2010). Sistem Komunikasi Indonesia. Jakarta : Rajawali Pers.

Pavlik, J. (2001). Journalism and New Media. Columbia University Press. 
Aisyah - Pemberdayaan Jurnalistik bagi Organisasi Kepemudaan ...

Rappaport, A.J. \& Leith, A.M. (2007). Brave New World? Legal Issues Raise By Citizen Journalism. Communication Lawyer, 25(2), 27-38. Retrieved from University of Queensland Library EReserve.

Salman, Ali et al. (2011). The Impact of New Media on Traditional Mainstream Mass Media. The Innovation Journal ; The Public Sector Innovayion Journal Vol 16(3).

Zaki,Ali. (2009). Kiat Jitu Membuat Website Tanpa Modal. Jakarta; Penerbit Elexmedia Komputindo. 